Ann. Sci. forest., 1980, 37 (4), 269-274.

\title{
Beech bark disease : what we do and do not know
}

\author{
D. R. HOUSTON \\ Principal Plant Pathologist \\ U.S. Department of Agriculture \\ Northeastern Forest Experiment Station \\ Hamden, Connecticut USA
}

Over the past 100 years, beech bark disease has spawned innumerable hypotheses of cause and effect and much conjecture about organism interactions. Yet this complex disease has received little substantive research at fundamental levels. The papers presented at this Colloquium are important for they add significantly to our understanding of beech bark disease. This paper presents, in brief and general terms, what we do and do not know about this disease.

\section{What we know - The disease}

We do know a great deal about the general « framework » of beech bark disease. We know that it begins when the felted beech coccus or beech scale, Cryptococcus fagisuga Lindinger ( $C$. fagi Bäerensprung) infests the living bark of Fagus sylvatica L. and F. grandifolia Ehrh. We know that feeding by $C$. fagisuga results in reduced growth and some bark necrosis. While some of us feel that $C$. fagisuga can cause extensive bark necrosis (Braun, 1977), most of us feel that under normal growth conditions, death of bark attributable to the insect alone is relatively limited (Boodle and Dallimore 1911 ; Ehrlich, 1934 ; Hartig, 1878 ; Parker, 1974 ; Shigo, 1964 ; Thomsen ef al., 1949).

We know that heavy feeding by $C$. fagisuga somehow renders bark tissues susceptible to successful colonization by normally very weakly pathogenic fungi, especially Nectria coccinea Pers. ex Fr. (Europe) and N. coccinea var. faginata Lohman, Watson and Ayers (North America). While some believe that these fungi are of relatively minor importance (Braun, 1977), the majority of us believe that they are primarily responsible for bark necrosis, and ultimately for tree mortality (Houston et al., 1979a).

\section{The insect}

Over the course of a century we have learned much about $C$. fagisuga. We know its life cycle and some of the ways that its probings affect the anatomy and physiology of beech bark (Braun, 1977 ; Ehrlich, 1934 ; Kunkel, 1968 ; Rhumbler, 1914). We 
have cursory knowledge of its distribution and dissemination patterns (Houston et al., $1979 b$ ), its predators (especially Chilocorus spp.), but have no information on its parasites (Ehrlich, 1934 ; Schindler, 1962 ; Thomsen ef al., 1949). We know that bark flora (lichens, mosses, algae) appear to influence the presence of $C$. fagisuga on individual trees (Ehrlich, 1934 ; Houston et al., 1979b) and that topographic relationships and probably other environmental factors affect the spread and development of insect populations (Ehrlich, 1934 ; Schindler, 1962 ; Parker, 1974 ; Thomsen ef al., 1949 ; Lyr, 1967 ; Zycha, 1951 ; Houston ef al., 1979b). While it appears that our knowledge about $C$. fagisuga is fairly broad, we know considerably less about the fungal components of the disease complex.

\section{The fungus}

We know that Nectria species are involved in beech bark disease but their exact identity is unclear. The fungi in Europe have been variously described as $N$. ditissima (Hartig, 1878), N. galligena (Thomsen et al., 1949), and N. coccinea (Ehrlich, 1934 ; Parker, 1974). In North America the fungus primarily associated with the disease was recognized as a variety of $N$. coccinea (Ehrlich, 1934) and later named N. coccinea var. faginata (Lohman and Watson, 1943). N. galligena has also been found to cause cankers on trees infested with $C$. fagisuga (Spaulding et al., 1936) and has recently been shown capable, together with $C$. fagisuga, of producing all of the symptoms of beech bark disease (Cotter, 1974).

Recent taxonomic studies comparing nutritional requirements and enzyme and protein patterns help clarify species relationships (Doyle, 1971 ; LaMadeleine, 1973 ; Stone, 1967). The sexuality and the cultural conditions for perithecia formation of Nectria coccinea and its North American variety have been investigated (Parker, 1976 ; Booth, 1966 ; Cotter, 1974). We know also, that these two Nectria species are attacked by the mycoparasite Gonatorrhodiella highlei A. L. Smith (Ayers, 1941 ; Blyth, $1949 a, b)$.

\section{Other organisms}

We have found that many other organisms are involved in this complex disease (Shigo, 1964). Some, including mosses, algae, and lichens appear to offer protection for and thus favor C. fagisuga (Ehrlich, 1934 ; Houston ef al., 1979b), while the heavy stroma of the bark fungus Ascodichaena rugosa Butin appears to discourage $C$. fagisuga on European beech (Houston, 1976a, 1979b). Other organisms have been invesfigated, including bark and wood boring beetles and decay fungi that contribute to the rapid deterioration of injured and killed trees and to the familiar symptom of stem breakage called «beech snap ». In North America young beech trees developing in areas that were severely affected earlier by beech bark disease are often heavily attacked by another scale insect, Xylococculus betulae (Perg.) Morrison (Shigo, 1962). Wounds created by $X$. befulae render young stems highly defective and in turn provide colonization sites for C. fagisuga and Nectria spp. (Shigo, 1962 ; Shigo, 1964 ; Houston. 1975). 
So, if it is true that we know all of this, we might logically ask the question : Why have a Beech Bark Disease Colloquium ? The answer can be stated very succinctly: What we do know about beech bark disease is not enough.

We cannot stop this disease - we still do not have enough understanding to prevent or reduce massive disease losses.

\section{What we do not know (Or, what we still need to know)}

\section{About the forest stand}

We do not know if we can manipulate the forest to reduce disease losses. Efforts to reduce the rale of increase in the causal agents or of disease development by stand thinning have thus far proved of little value (Crosby and Bjorkbom, 1958). Results from similar experiments in Great Britain are reported at this Colloquium. One factor not yet explored critically is the effect of various species mixtures and densities on disease development.

\section{About the host trees}

We need studies to clarify the potential influence of environmental factors in predisposing beech trees to infestation by C. fagisuga and perhaps to infection by Nectria spp. Whether fluctuations in insect populations observed in Europe and in North America are due to influences of environment on host tree susceptibility, on the insect itself, or both is not clear - and is very difficult to ascertain. This situation is confounded further by the probable occurrence of natural host resistance (at least in F. grandifolia) to C. fagisuga, and in North America to Xylococculus betulae and host tolerance to the associated Nectria species (Shigo, 1962 ; Shigo, 1964 ; Houston, 1975 ; Camp, 1951).

Studies are needed to clarify the validity and nature of apparent host resistance, and how such resistance is influenced by environment, by tree age, and by biotic factors that appear to either enhance or reduce local tissue susceptibility. Such factors could include wound agents (e. g. X. betulae in North America, N. ditissima in Europe) and bark coverings such as lichens (e. g. Lecanora conizioides in parts of Europe) ; or fungi (e. g. Ascodichaena rugosa in Great Britain).

\section{About the insect}

Even though we recognize that $C$. fagisuga is the necessary precursor to severe Nectria infection, we lack a good understanding of the factors that predispose trees or tissues to its attack, and of environmental factors that limit or encourage its development. We also have little insight into how the insect alters bark tissues biochemically in favor of Nectria spp. In fact, it is still unclear whether the fungi enter trees directly via stylet wounds, or indirectly through cracks created as bark dries out as a consequence of insect feeding. And, although a number of predators are known, their role in population regulation and their potential for manipulation (in many parts of the world) is unclear. 


\section{About the fungi}

The role of fungi in beech bark disease is still controversial. Individual researchers have vacillated in their conception of Nectria's role - one time describing it as a necessary part of the causal complex, and another time as a strictly secondary organism (e. g. Rhumbler, 1914 ; Nusslin and Rhumbler, 1922 ; Rhumbler, 1931). This latter view has surfaced again recently (Braun, 1977). The potential role of other Nectria species in beech bark disease is not entirely clear. In North America both $N$. coccinea var. faginata and N. galligena have been associated with the disease (Spaulding et al., 1936 ; Cotter, 1974), and in the United States and in Europe, the isolation of other Nectria species from those suspected of having beech bark disease is sufficiently frequent to warrant a close look at possible relationships.

A major question still unanswered is whether $N$. coccinea var. faginata is native to North America or was introduced along with $C$. fagisuga. Aside from one report (Spaulding ef al., 1936) the fungus has not been isolated from areas free of $C$. fagisuga in North America (Cotter, 1974). But since it also is not known to occur in Europe, its origin is still in doubt (Parker, 1974).

And finally, the mycoparasite, G. highlei, first studied in Great Britain (Blyth, 1949a, b) and then in North America (Ayers, 1941, Ehrlich, 1942, Gain and Barnett, 1970) was recently found associated with beech bark disease in Great Britain (Houston $1976 b)$ and in France (Perrin, 1977). The effects of $G$. highlei on Nectria in nature, and its potential for exploitation, are unknown.

\section{The Look Ahead}

We cannot effectively cope with beech bark disease with only current information. Aside from recommendations to avoid growing beech on high-yield sites, especially on slopes, or to salvage diseased trees as soon as possible, we can offer the forest manager nothing that will enable him to prevent the disease or to reduce losses in the long run. It is clear that answers to many of the questions posed above are necessary before sound recommendations can be made for coping with the disease through forest management practices. Especially appealing to many of us is the possibility that with increased understanding one or more natural controlling factors may be exploitable, especially genetic resistance, predators of the insect, or parasites of the pathogen.

The promises, just over the horizon, are what have brought us together for this Colloquium. I hope our inferactions here will not only benefit our respective current research programs but will also trigger future cooperative research ventures between our countries and continents. It is highly probable that the solutions to this international complex problem will be arrived at only through an international research thrust. 


\title{
Résumé
}

\author{
Maladie de l'écorce du hêtre \\ Un bref commentaire sur nos connaissances ef ses lacunes
}

Nous savons que la maladie de l'écorce du hêtre commence par l'infestation de la cochenille Cryptococcus fagisuga dont l'action nutritive rend l'écorce vulnérable à un parasite de faiblesse Nectria coccinea (Europe) ou sa var. faginata (Amérique du Nord). Les connaissances acquises sur l'insecte comme sur le champignon sont considérables. Cependant notre compréhension des facteurs prédisposant l'arbre ou les tissus à la maladie, comme celle de l'influence de l'environnement sur son développement, reste insuffisante.

\section{References}

AYERS T. T., 1941. The distribution and association of Gonatorrhodiella highlei with Nectria coccinea in the United States. Mycologia, 33, 178-187.

BLYTH W., 1949a. Studies on Gonatorrhodiella higheli A. L. Smith. Trans. Bot. Soc., Edinburgh, $35,157-$ 179.

BLYTH W., 1949b. Association of Gonaforrhodiella highlei with Nectria species. Nature, 4163, 274.

BOODLE L. A. and DALLIMORE W., 1911. Report on investigations made regarding « beech coccus ». (Cryptococcus fagi Bäerensprung). R. Bot. Gard., Kew, Bull. Misc. Inf., 1911, 332-343.

BOOTH C., 1966. The genus Cylindrocarpon. Commonw. Mycol. Inst. Mycol. Pap. No. 104. Kew, Surrey, England. 56 p.

BRAUN H. J., 1977. Das Rindensterben der Buche, Fagus sylvatica L., verursacht durch die Buchenwallschildlaus Cryplococcus fagi Bar. Eur. J. For. Pathol., 7, 76-93.

CAMP W. H., 1951. A study of relative virulence of beech bark disease on the several types of forest beech present in eastern Canada and Maine. Acad. Nat. Sci. Philadelphia. Am. Philos. Soc. Yearb., 1951, 180-183.

COTTER H. V. T., 1974. Beech bark disease : fungi and other associated organisms. M. S. Thesis. Univ. New Hampshire, Durham, 137 p.

CROSBY D. and Bjorkbom J. C., 1958. Timely salvage can reduce losses from beech scale-Nectria attack. U. S. Dep. Agric. For. Serv. Res. Note NE-82, 82 p.

DOYLE A. F., 1971. A preliminary chemosystematic investigation of the genus Nectria (Ascomycetes, Hypooreales). Ph. D. Thesis, Columbia Univ., New York, N. Y., 152 p.

EHRLICH J., 1934. The beech bark disease, A Nectria disease of Fagus following Cryptococcus fagi (Baer.). Can. J. For. Res., 10, 593-692.

EHRLICH J., 1942. Occurrence of Gonatorrhodiella highlei with Nectria species. Nature, 4163, 274.

GAIN R. E. and BARNETT H. L., 1970. Parasitism and axenic growth of the mycoparasite Gonatorrhodiella highlei. Mycologia, 62, 1122-1129.

HARTIG R., 1878. Die krebsartigen Krankheiten der Rotbuche. Z. Forstund Jagdwes, 9, $377-383$.

HOUSTON D. R., 1975. Beech bark disease, the aftermath forests are structured for a new outbreak. J. For., 73 (10), 660-663.

HOUSTON D. R., 1976a. Protection against beech scale, Cryptococcus fagi, by Dichaena rugosa, a bark fungus of European and American beech trees. (Abstr.) Proc. Am. Phytopathol. Soc., 3, 306.

HOUSTON D. R., 1976b. Studies on Gonatorrhodiella highlei, a mycoparasite of Nectria spp. associated with beech bark disease in England and North America. (Abstr.). Proc. Am. Phytopathol. Soc., 3 , 306.

HOUSTON D. R., PARKER E. J., PERRIN R. and LANG, K., 1979a. Beech bark disease : A comparison of the disease in North America, Great Britain, France and Germany. Eur. J. For. Pathol. (In press).

HOUSTON D. R., PARKER E. J. and LONSDALE D., 1979b. Beech bark disease : patterns of spread and development of the initiating agent. Cryptococcus fagisuga. Can J. For. Res. (In press).

KUNKEL H., 1968. Untersuchugen über die Buchenwollschildlaus Cryptococcus fagi Bär. (Insecta, coccina) einen Vertreter der Rindenparenchymsauger. Z. angew. Entomol., 61 (4), 373-380.

LAMADELEINE L. A., 1973. Electrophoretic differentiation of several species of Nectria. M. S. Thesis, Univ. New Hampshire, Durham, 36 p.

LOHMAN M. L. and WATSON A. J., 1943. Identity and host relations of Nectria species associated with diseases of hardwoods in the eastern States. Lloydia, 6 (2), 77-108.

LYR H., 1967. Über die Ursachen der Buchenrindennekrose. Arch. Forsfw., 16, 6-9, 803-807. 
NUSSLIN O. and RHUMBLER L., 1922. Die Buchen-Wollschildlaus (Coccus (Cryptococcus) fagi) Bäerspr. In Forstinsektenkunde. Berlin, Paul Parey, 3, Aufl., 125-139.

PARKER E. J., 1974. Beech bark disease. Ph. D. Thesis, Univ. Surrey, Guildford, Surrey, GU2 5XH, IK, $161 \mathrm{p}$.

PARKER E. J., 1976. Production of Nectria coccinea perithecia in culture on a natural medium. Trans. Br. Mycol. Soc., 66, 519-520.

PERRIN M. R., 1977. Gonatorrhodiella highlei A. L. Smith hyperparasite de Nectria coccinea Pers. ex Fries un des agents de la maladie du hêtre. Acad. Agric. France. Extrait P.-V. Séance 5 janv. 1977, p. $67-70$.

RHUMBLER L., 1914. Die Buchenrinden-Wollaus (Cryptococcus fagi) und ihre Bekampfung. J. Neumann, Neudamm, n. d., 32 p. (Abstr. in Res. Appl. Entomol. A, 2, 571-572).

RHUMBLER L., 1931. Über das Schicksal der von der Bucherinden-Wollaus (Cryptococcus fagi Bsp.), befallenen Buchen. Z. angew. Entomol., 18, 590-614.

SCHINDLER U., 1962. Erfahrungen mit der Buchenwollschildlaus. Forts.-u. Holzwirtsch., 17 (15).

SHIGO A. L., 1962. Another scale insect on beech. U. S. Dep. Agric. For. Serv. Res. Pap. NE-168, 13 p.

SHIGO A. L., 1964. Organism interaction in the beech bark disease. Phytopathology, 54 (3), 263-269.

SPAULDING P., GRANT T. J. and AYERS T. T., 1936. Investigations of Nectria diseases in hardwoods of New England. J. For., 34, 169-179.

STONE G. L., 1967. A physiological study of Nectria coccinea var. Coccinea (Pers.) Fr. and Nectria coccinea var. faginata Lohm., Wats., and Ayers. M. S. Thesis, State Univ. N. Y., Syracuse.

THOMSEN M., BUCHWALD N. F. and HAUBERG P. A., 1949. Angreb af Cryptococcus fagi, Nectria galligena og andre parasiter paa bøg I Danmark 1939-1943. Forstl. Forsøkvais. Dan., 18, 97-326. (English summary).

ZYCHA H., 1951. Das Rindensterben der Buche. Phytopathol. Z., 17 (4), 444-461. 